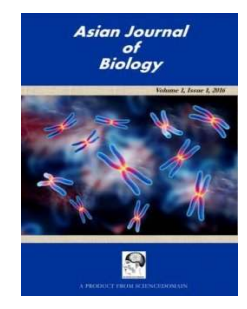

\title{
Aspects of the Biology of Silver Catfish (Chrysichthys nigrodigitatus) in Nwaniba River, Southeast Nigeria
}

\author{
I. K. Esenowo ${ }^{1^{*}}$, A. A. A. Ugwumba ${ }^{2}$, I. I. Umoh ${ }^{1}$ and A. B. Andem ${ }^{3}$ \\ ${ }^{1}$ Department of Zoology, University of Uyo, Uyo, Akwa Ibom State, Nigeria. \\ ${ }^{2}$ Department of Zoology, University of Ibadan, Ibadan, Oyo State, Nigeria. \\ ${ }^{3}$ Department of Zoology and Environmental Biology, University of Calabar, Cross River State, Nigeria.
}

\section{Authors' contributions}

This work was carried out in collaboration between all authors. Author IKE managed the literature searches and wrote the first draft of the manuscript. Author AAAU designed the study and wrote the protocol while authors IIU and ABA performed the statistical analysis and managed the analyses of the study. All authors read and approved the final manuscript.

Article Information

DOI: $10.9734 / A J O B / 2017 / 34408$

Editor(s):

(1) Manojit Bhattacharya, Department of Zoology, Vidyasagar University, Midnapore, India.

Reviewers:

(1) Alicia Whatley, Troy University, USA.

(2) U. D. Enyidi, Michael Okpara University of Agriculture, Abia State, Nigeria. Complete Peer review History: http://www.sciencedomain.org/review-history/20034

Original Research Article

Received $26^{\text {th }}$ May 2017

Accepted $10^{\text {th }}$ July 2017

Published 14 $4^{\text {th }}$ July 2017

\section{ABSTRACT}

The Aspects of the Biology of the Catfish (Chrysichthys nigrodigitatus) were investigated from August to October 2015 in Nwaniba River, Akwa Ibom State, Nigeria. A total of two hundred (200) specimens were analyzed for gut contents using Numerical and Frequency of Occurrence methods. The results revealed that the species feed on various food items ranging from plant origin to animal materials with dietary preference classified into eight major groups consisting of Crustaceans 39 (23.2\%), Fish parts $26(15.6 \%)$, Detritus $23(13.7 \%)$, Plant parts $20(11.9 \%)$, Undefined $20(11.9 \%)$, Mollusca $19(11.3 \%)$, Insects $13(7.7 \%)$, and Nematodes $8(4.7 \%)$ respectively. Of the 200 stomachs examined, 35 (17.5\%) were empty stomachs, $80(40 \%)$ had quarter-full stomachs, 50 $(25 \%)$ had half-full stomachs, $13(6.5 \%)$ had three quarter-full stomachs and $22(11 \%)$ had full stomachs. The condition factor calculated for the species varied during the studies period with a mean value of 0.77 in August, 0.72 in September and 0.73 in October. Based on the food items 
isolated in the gut, the species could be considered as an Omnivorous fish in Nwaniba River. Further research should be done to ascertain the food preference of the species over a longer period of time covering both wet and dry season. This will enable definite conclusion on its food preference.

Keywords: Chrysichthys nigrodigitatus; diet composition; condition factor; Nwaniba River.

\section{INTRODUCTION}

Fishes are sources of food for human beings and other animals, rich in proteins and vitamins, especially, vitamin A (Retinol) $[1,2,3]$. Statistics have shown that fish accounts for more than forty percent of the protein diet of two-thirds of the global population $[4,5]$. It is unfortunate that the protein requirement of most African countries still grossly outweighs its supply. In Nigeria, less than $40 \%$ of the total protein requirement by the people is met, out of which fish constitutes about $41 \%$ [6].

As the human population inevitably increases, the demand for fish as a source of protein will grow [7]. Fishes such as those in the family Claroteidae are highly used and commercialized. The commercially important fish species in this family are the Catfish (Chrysichthys species) known as "Inanga" in lbibio language. Chrysichthys nigrodigitatus (Lacepede 1802) is a common silver colored African catfish occurring in Nigeria and several West African countries. It is a highly valuable fish species amongst the indigenous African populations [8].

All fish require energy which must be obtained from its food sources for growth, reproduction and migration $[9,10]$. Understanding food and feeding habits of fish is useful to all scientists who are concerned with any aspect of fisheries [11]. The study of dietary habits of fishes based on stomach content analysis is widely used in fish biology and ecology to indicate the position of a species within a food web and to provide information on the contribution of different prey items to the diet [12]. It also help in understanding food consumption, feeding and assimilation rates, catabolism, habitat segregation [13], defining predator-prey relationships, estimation of trophic level [14] and in the creation of trophic models as a tool for understanding complex ecosystems [15].

Chrysichthys species has been found to be a typical example of fish without strict feeding habit. It is regarded as an omnivore, because of its ability to use just any food material present in its environment [16]. Royle [17] reported that potential food resources of fish consist of all materials present in its environment. Fishes have been known to feed on a wide variety of items ranging from sand particles, phytoplankton, zooplanktons, leaves, roots, crustaceans, insects, insect larvae, worms, fishes etc, $[18,19,20]$. The more so Idodo-Umeh [21] reported that $C$. auratus, $C$. nigrodigitatus and $C$. furcatus were omnivorous bottom feeders.

Condition factor is also a useful index for monitoring of feeding intensity, age, and growth rates in fish [22]. In fisheries science, it is used to compare the "condition", "fatness" or wellbeing of fishes. It is based on the hypothesis that heavier fish of a particular length are in a better physiological condition [14]. It is strongly influenced by both biotic and abiotic environmental conditions and can be used as an index to assess the status of the aquatic ecosystem in which fish live [23]. Various works have been done on the diets of Chrysichthys nigrodigitatus, and other fish species from various rivers in Nigeria and few other lakes and reservoirs [24,25,21,26,27,16]. In Nwaniba River, few or no extensive work has been carried out on some aspects of the biology of commercial important species. Therefore, this present paper is a contribution to understanding the biology of Chrysichthys nigrodigitatus which include diet composition, stomach fullness and condition factor with a view to developing its aquaculture.

\section{MATERIALS AND METHODS}

\subsection{Study Area}

Nwaniba River lies between 52'51" North of latitude and 82'41" East of longitude (Fig. 1). The annual rainfall in this region is about 2500 $\mathrm{mm}$ with a mean annual temperature of $32{ }^{\circ} \mathrm{C}$ and a relative humidity of $75 \%$. The source of this river is traced to two flood plains; one flows from Itam River in Itu Local Government Area through Mbiakong River, while the other from Obot-Ifiayong creek down to this river, and runs through Otoh-nkemba where it flows to Ibiakuuruan, Oron, Calabar, Cameroun and Atlantic Ocean. 
The riverbank is covered with vegetation such as Elephant grass (Pennisetum purpureum), shrubs and trees, Screw pine (Pandamus spp), Mangrove palm (Nypha fruticans), Pneumatophorous plant with prop roots, and other tropical hydrophytes for example Water hyacinth (Eichhorina crassipes), Water lilies (Nymphaea lotus), Ceratophyllum demersum, and Bladderwort (Utricularia spp) e.t.c. The River also has a beach called Esuk Nwaniba, which serves as harbor for fishermen. It is at this beach that the fishes are sold out to the fish sellers for public consumption or other purposes.

\subsection{Collection of Samples}

Samples of Chrysichthys nigrodigitatus were obtained monthly between August and October 2015 from the commercial landings of the fishermen using gill-nets and transported in icechest box to the University of Uyo Zoology laboratory for fresh examination. Various sizes of Chrysichthys nigrodigitatus ranging from small, medium to large were sorted out and used for the study.

Chrysichthys nigrodigitatus samples were identified using key guides of Olasebikan and
Raji [28]. Each specimen was measured to the nearest $0.1 \mathrm{~cm}$ total length (TL) using a measuring board of $1-50 \mathrm{~cm}$ (range) and weighed fresh using a digital balance to the nearest $0.1 \mathrm{~g}$. A longitudinal incision was made with the aid of stainless steel scissors and forceps along the mid-ventral line from the mouth to the anus to expose the visceral organs and the gut was carefully removed with pair of throngs.

Fulton's condition factor (CF) was determined using the expression according to Ricker [29]:

$$
K=(W / L 3) 100
$$

Where,

$$
\begin{aligned}
& K=\text { condition factor, } \\
& W=\text { total weight }(\mathrm{g}), \\
& L=\text { total length }(\mathrm{cm}) \text { and } \\
& 3=\text { the cubic relationship between length } \\
& \text { and weight. }
\end{aligned}
$$

\subsection{Stomach Fullness Classification}

Stomach contents classification of Chrysichthys nigrodigitatus based on degree of fullness was determined according to methods by Ugwumba and Ugwumba [30].

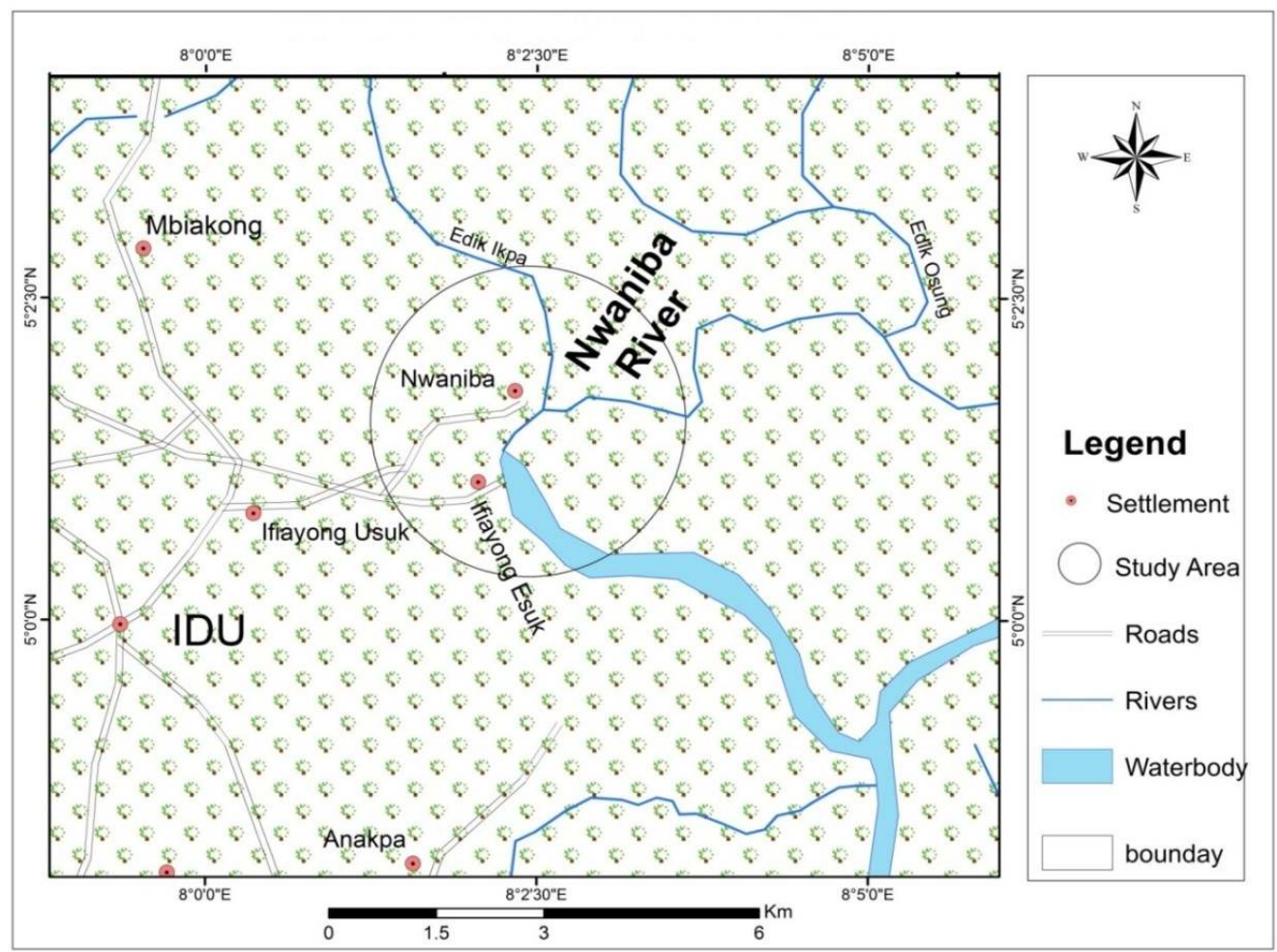

Fig. 1. Map of study area showing Nwaniba River 
The condition of the stomach was determined visually and categorized as follows:

$$
\begin{aligned}
0 / 4 & =\text { empty stomach } \\
1 / 4 & =\text { one quarter full stomach } \\
2 / 4 & =\text { half full stomach } \\
3 / 4 & =\text { three quarter full stomach } \\
4 / 4 & =\text { full stomach }
\end{aligned}
$$

\subsection{Identification of Stomach Contents}

The stomach contents were emptied into petridish to which $10 \%$ saline was added to disperse the contents. The food items were sorted into categories, viewed under microscope and identified to species level where possible using key guides by Mellanby [31]. Stomach contents were analyzed using two (2) methods, frequency of occurrence and numerical methods.

\subsection{Frequency of Occurrence}

The number of stomachs in which each food item occurred was sorted out and expressed as percentage of the total number of fish stomachs examined according to Bowen [32]:

$$
\mathrm{F} 1=100 \mathrm{ni} / \mathrm{n}
$$

Where

F1: frequency of occurrence of the $i$ food item in the sample

ni: number of stomachs in which the i item is found

$\mathrm{n}$ : number of stomachs with food in the sample.

\subsection{Numerical Method}

The number of individual of each food item was counted and summed up to give the total of each food item, then the grand total of all items was calculated and expressed as percentage of the overall items found in each stomach [33].

\subsection{Statistical Analysis}

All data collected were subjected to statistical analysis using statistical package for social science (SPSS 2007) software. The coefficient of regression was used to assess the length-weight relationships

\section{RESULTS}

A total of 200 species of $C$. nigrodigitatus was collected from Nwaniba River. Table 1 shows the numerical abundance and frequency occurrence of diet Composition. Chrysichthys nigrodigitatus fed on food items that are of plant and animal sources. These are grouped into detritus, fish parts, plant parts, crustacean, insects, nematodes, mollusca and unidentified materials for both frequency of occurrence and numerical methods. Crustacean was determined as the highest item ingested by the fish while nematodes were the lowest items.

Of the 200 stomachs examined, $17.5 \%$ were empty stomachs, $40 \%$ had quarter-full stomachs, $25 \%$ had half-full stomachs, $6.5 \%$ had three quarter-full stomachs and $11 \%$ full stomachs (Table 2), while Table 3 shows the monthly diet composition. However, the morphometric parameters of Chrysichthys nigrodigitatus from Nwaniba River for the period of sample are shown on Table 4.

\section{DISCUSSION}

The morphology of Chrysichthys is adapted for bottom feeding although stomach contents may prove otherwise as the variety of food items contained in the stomach often reflect the ability of the fishes to obtain food from different locations [24]. However, Idodo-Umeh [34] stated that morphological features couldn't limit Chrysichthys as exclusive bottom feeders, as stomach content indicates food items from different locations. The wide food spectrum of $C$. nigrodigitatus is an indication of flexibility in trophic level, which gives the fish ecological advantage to feed effectively on different categories of diet based on the availability of the food items $[35,26]$.

The result of this study shows that Chrysichthys nigrodigitatus from Nwaniba River fed on wide range of items from plant to animal materials where Crustacean is the predominant item. This is in agreement with findings of Atobatele, [36] who reported that $C$. nigrodigitatus and $C$. auratus had similar food items, with Crustacean dominating in terms of percentage occurrence and numerical abundance. Other food items included mollusks, plant parts, fish parts, insects, detritus and others, indicating that $C$. nigrodigitatus is an omnivorous. Similar results have been reported for $C$. nigrodigitatus from Lekki lagoon [37,34]. The wide variety of items encountered in the stomachs of the fish species show that they are non-selective in feeding and it appears that they are capable of utilizing different sources of food. Shep et al. [38] observed that such feeding on a wide range of food comprising both plants and animal, making the fish euryphagous. However, Ekpo et al. [39] also 
reported that the index of food dominance enables these fishes to be categorized into 4 broad groups: planktophagous, herbivorous, predators and detritivores. The inclusion of sand grains in the stomach of fish has been attributed as an accidental ingestion along with other food items [25].

Feeding intensity of fish can be determined based on degree of fullness of stomach [16]. The relatively high percentage of almost empty stomach suggests that the quantity of food was low during the period of this study. However, result of stomach fullness analysis is not in line with findings of Yem et al. [16] who recorded relatively high percentage of full stomach, which suggests that food was abundant throughout the period of study in Kainji Lake, Nigeria.

The result of Chrysichthys nigrodigitatus from Nwaniba River shows low value for Condition factor (K) during the periods of study. This agrees with findings of Atobatele and Ugwumba [24] who reported low condition factor for $C$. nigrodigitatus after the second peak in September and October and may be due to reduced availability of food and prey items. According to Bagenal and Tesch [14], if the condition factor " $k$ " $\geq 0.5$, the fish is in a good condition but if the value of " $k$ " $\leq 0.5$, the fish is assumed to be in bad condition. In this study, the overall mean condition factor value "k" estimated was 0.74 which is $>0.5$, indicating that the population was in good condition. However, Uneke, [27] recorded overall mean condition factor value " $\mathrm{k}$ " to be 1.21, indicating that the population was in good condition. The exact relationship between length and weight differs within species and sometimes reflects food availability and growth within the period prior to sampling [40,27]. However, these conditions are variable and dynamic, individual average condition of each population varies seasonally and yearly.

Table 1. Numerical abundance and frequency occurrence of diet Composition of Chrysichthys nigrodigitatus from Nwaniba River

\begin{tabular}{|c|c|c|c|}
\hline Food items & Numerical abundance $(\mathrm{N})$ & $\begin{array}{l}\text { Relative percentage } \\
\text { occurrence (\%) }\end{array}$ & Total (\%) \\
\hline \multicolumn{4}{|l|}{ Detritus } \\
\hline Mud & 13 & 7.74 & 13.7 \\
\hline $\begin{array}{l}\text { Sand particles } \\
\text { Fish Parts }\end{array}$ & 10 & 5.95 & \\
\hline \multicolumn{4}{|l|}{ Fish Parts } \\
\hline Partially digested fish & 21 & 12.5 & 15.5 \\
\hline \multicolumn{3}{|l|}{ Plant Parts } & \\
\hline Netrium & 2 & 1.19 & \\
\hline Anabaena & 6 & 3.57 & 11.9 \\
\hline Spirogyra & 10 & 5.95 & \\
\hline Macrophyte matter & 2 & 1.19 & \\
\hline \multicolumn{4}{|l|}{ Crustaceans } \\
\hline Corophium & 3 & 1.79 & \\
\hline Neomysis & 16 & 9.52 & \\
\hline Streptocephalus & 1 & 0.59 & 23.2 \\
\hline Daphinia & 13 & 7.74 & \\
\hline Mysis & 2 & 1.19 & \\
\hline Estheria & 4 & 2.38 & \\
\hline \multicolumn{4}{|l|}{ Insects } \\
\hline Stonefly nymph & 0 & 0 & \\
\hline Capnia & 6 & 3.57 & 7.74 \\
\hline Perlinella & 3 & 1.79 & \\
\hline Choroterpes & 4 & 2.38 & \\
\hline Nematodes & 8 & 4.76 & 4.76 \\
\hline \multicolumn{4}{|l|}{ Mollusca } \\
\hline Ancylus species & 13 & 7.74 & 11.3 \\
\hline Pisidium & 6 & 3.57 & \\
\hline \multicolumn{4}{|l|}{ Others } \\
\hline Diatoms & 8 & 4.74 & \\
\hline Unidentified & 12 & 7.14 & 11.9 \\
\hline
\end{tabular}


Table 2. Stomach fullness analysis of Chrysichthys nigrodigitatus from Nwaniba River

\begin{tabular}{|c|c|c|c|c|c|c|}
\hline Month & $\begin{array}{l}\text { Number of stomach examined } \\
\text { (N) }\end{array}$ & $\begin{array}{l}\text { Empty stomach (0/4) } \\
\text { fullness }\end{array}$ & $\begin{array}{l}1 / 4(25 \%) \\
\text { fullness }\end{array}$ & $\begin{array}{l}1 / 2(50 \%) \\
\text { fullness }\end{array}$ & $\begin{array}{l}3 / 4(75 \%) \\
\text { fullness }\end{array}$ & $\begin{array}{l}3 / 4(100 \%) \\
\text { fullness }\end{array}$ \\
\hline August & 80 & $17(21.3 \%)$ & $28(35 \%)$ & $17(21.3 \%)$ & $5(6.2 \%)$ & $13(16.2 \%)$ \\
\hline September & 72 & $8(11.1 \%)$ & $31(43.1 \%)$ & $21(29.1 \%)$ & $5(6.9 \%)$ & $6(8.3 \%)$ \\
\hline October & 48 & $10(20.8 \%)$ & $21(43.8 \%)$ & $12(25 \%)$ & $3(6.2 \%)$ & $3(6.2 \%)$ \\
\hline Total & 200 & 35 & 80 & 50 & 13 & 22 \\
\hline
\end{tabular}

Table 3. Monthly diet composition of Chrysichthys nigrodigitatus from Nwaniba River

\begin{tabular}{|c|c|c|c|c|c|c|c|c|}
\hline \multirow[t]{2}{*}{ Month } & \multicolumn{8}{|c|}{ Diet composition } \\
\hline & Detritus & Fish parts & Plant parts & Crustaceans & Insects & Nematodes & Mollusca & Others \\
\hline August & $6(11.1 \%)$ & $10(18.5 \%)$ & $9(16.7 \%)$ & $10(18.5 \%)$ & $2(3.7 \%)$ & $0(0 \%)$ & $4(7.4 \%)$ & $13(24.1 \%)$ \\
\hline September & $8(13.1 \%)$ & $9(14.8 \%)$ & $7(11.5 \%)$ & 19 (31.1\%) & $5(8.1 \%)$ & $3(4.9 \%)$ & $6(9.8 \%)$ & $4(6.6 \%)$ \\
\hline October & $9(16.9 \%)$ & $7(13.2 \%)$ & $4(7.5 \%)$ & $10(18.9 \%)$ & $6(11.3 \%)$ & $5(9.4 \%)$ & $9(16.9 \%)$ & $3(5.7 \%)$ \\
\hline Total & $23(13.7 \%)$ & $26(15.6 \%)$ & $20(11.9 \%)$ & $39(23.2 \%)$ & $13(7.7 \%)$ & $8(4.7 \%)$ & $19(11.3 \%)$ & $20(11.9 \%)$ \\
\hline
\end{tabular}

Table 4. Morphometric parameters of Chrysichthys nigrodigitatus from Nwaniba River

\begin{tabular}{|c|c|c|c|c|c|c|c|c|c|}
\hline \multirow[t]{2}{*}{ Months } & \multicolumn{9}{|c|}{ Parameters } \\
\hline & $\begin{array}{l}\text { No. } \\
\text { of samples }\end{array}$ & $\begin{array}{l}\text { Length range } \\
(\mathrm{cm})\end{array}$ & $\begin{array}{l}\text { Mean length } \\
(\mathrm{cm}) \pm S E\end{array}$ & $\begin{array}{l}\text { Weight range } \\
\text { (g) }\end{array}$ & $\begin{array}{l}\text { Mean weight } \\
(\mathrm{g}) \pm \mathrm{SE}\end{array}$ & a & b & $\mathbf{r}$ & $\mathbf{K}$ \\
\hline August & 80 & $10.5-22.2$ & $15.134 \pm 0.239$ & $10.2-51.04$ & $26.73 \pm 1.097$ & -1.271 & 2.271 & 0.868 & 0.77 \\
\hline September & 72 & $11.2-19.9$ & $15.008 \pm 0.221$ & $12.1-50.02$ & $24.21 \pm 0.916$ & -1.071 & 2.076 & 0.857 & 0.72 \\
\hline October & 48 & $11.5-17.0$ & $14.073 \pm 0.189$ & 13.4-37.54 & $20.34 \pm 0.674$ & -0.753 & 1.789 & 0.776 & 0.73 \\
\hline
\end{tabular}




\section{CONCLUSION}

Chrysichthys nigrodigitatus from Nwaniba River fed on wide range of food items from plant to animal materials and can therefore be said to be omnivorous, the high percentage of almost empty stomachs during period of sampling, indicates low quantity of food materials, hence the fish exhibited allometric growth pattern.

However, Chrysichthys nigrodigitatus is among the abundant commercially important fish found in the River and common especially during the wet season. Since Chrysichthys nigrodigitatus from Nwaniba River has aquaculture potential, culture trial is therefore recommended to sustain its demand as source of protein requirement. Hence, Plant and animal components should constitute the major diet of Chrysichthys nigrodigitatus. It is hoped that the present data will complement the limited information on the food, feeding habit, condition factor and lengthweight relationship of Chrysichthys nigrodigitatus in Nwaniba River, and prove useful in the management and conservation of this important commercial fish species.

Further research should be done to ascertain the food preference of the species over a longer period of time covering both wet and dry season. This will enable definite conclusion on its food preference for domestication and cultivability.

\section{COMPETING INTERESTS}

Authors have declared that no competing interests exist.

\section{REFERENCES}

1. Alune E, Andrew G. Fishes. Cambridge University Press, London; 1996.

2. Osuigwe DI, Obiekezie Al. Assessment of the growth performance and feed utilization of fingering Heterobranchus longifilis fed raw and boiled jackbean (Canavalia ensiformis) seed meal as fishmeal substitute. J. Fish. Int. 2007;2:3741.

3. Fayeofori GB. Food and feeding habits of Tilapia guineensis (1862) in Rumuolumeni creek, Niger Delta, implications for pisciculture. J. Life Sci. 2013;5(1):41-45.

4. Eyo AA. Utilization of freshwater fish species in Nigeria. Proceedings of the 10th Annual Conference of Fisheries Society of
Nigeria, Abeokuta, 16th - 20th November; 1992.

5. FAO. World production of fish, crustaceans and mollusks by major fishing areas. Fisheries Information Data and Statistic Unit (FIDI), Fisheries Department, F.A.O Rome; 1999.

6. Bernard BB, Mfon TU, Utibe DI. Preliminary study on the aspects of the biology of snakehead fish Parachanna obscura (Gunther) in a Nigerian wetland. African Journal of Food, Agriculture, Nutrient and Development. 2011;11(2):4456.

7. Abolarin MO. A new species of Henneguya (Myxosporida, protozoa) from West African catfish, Clarias lazera (Val; with a review of the Genus Henneguya thelohan). The African Journal of Tropical Hydrobiology and Fisheries. 1996;1:93-105.

8. Akinsanya $B$, Otubanjo OA, Ibidapo CA. Helminth bioload of Chrysichthys nigrodigitatus (Lacepede 1802) from Lekki Lagoon, Lagos Nigeria. Turk. J. Fish. Aquat. Sci. 2007;7:83-87.

9. Anupama RP. Value-added food: Single cell protein. Biotechnol Adv. 2000;18(6): 459-479.

10. Oronsaye CG, Nakpodia FA. A comparative study of the food and feeding habits of Chrisichtys nigrodigitatus and Brycinus nurse in the tropical river. Pak. J. Sci. Ind. Res. 2005;48:118-121.

11. FAO. Field guide to the freshwater fishes of Tanzania. Rome: Food and Agricultural Organization; 1992.

12. Owolabi OD. The dietary habit of the upside down catfish, Synodontis membranaceus (Osteichthyes; Mockhokidae) in Jebba Lake, Nigeria. Ph. D. Thesis, University of Ilorin, Nigeria; 2008.

13. Gomos A, Yilmaz M, Polat N. Relative importance of food items in feeding of Chondrostoma regium Heckel, 1843, and its relation with the time of annulus formation. Turk. J. Zool. 2002;26:271-278.

14. Bagenal TB, Tesch FW. Methods for assessment of fish production in freshwaters. T. B. Bagenal (9 Ed.) I.B.P. Handbook No. Edn 33. Oxford Blackwell Publications; 1978.

15. Lopez-Peralta $\mathrm{RH}$, Arcila $\mathrm{CA}$. Diet composition of fish species from Sourthern continental shelf of Colombia. Naga World Fish Cent. Quart. 2002;25:23-29. 
16. Yem IY, Bankole NO, Ogunfowora O, Ibrahim B. Food habit of the catfish Chrysichthys nigrodigitatus (Geoffrey Saint Hilaire, 1808) in Kainji Lake, Nigeria. Nat. Sci. 2009;7:17-22.

17. Royle W. Observation on feeding habits of Clarias barrage experimental pond found in food scheme technology. 2001;5(2):7679.

18. Omondi R, Yasindi AW, Magana AM. Spatial and temporal variations of zooplankton in relation to some environmental factors in lake Baringo, Kenya. Eger. J. Sci. Technol. 2011;11:29-50.

19. Shalloof KAS, Khalifa N. Stomach contents and feeding habit of Oreochromis niloticus (L.) from Abu-Zabal Lakes, Egypt. World Appl. Sci. J. 2009;6(1):1-5.

20. Yalcin S, Solak U, Solak K. Stomach contents of the catfish (Clarias gariepinus Burchell, 1822) in the River Asi, Turkey. Turk. J. Zool. 2001;25:461-468.

21. Idodo-Umeh $G$. The feeding ecology of bagrid species in River Ase, Niger Delta, southern Nigeria. Trop. Freshwater Biol. 2002;11:47-68.

22. Ndimele PE, Kumolu-Johnson CA, Aladetohun NF, Ayorinde OA. Lengthweight relationship, condition factor and dietary composition of Sarotherodon melanotheron, Ruppell, 1852 (Pisces: Cichlidae) in Ologe Lagoon, Lagos, Nigeria. Agric. Biol. J. N. Am. 2010;1:584590.

23. Anene A, Keke RI. Some aspects of the reproductive biology of Tilapia zilli from a small lake in Imo State, Nigeria. Animals Production Research Advance. 2005;1(2): 70-75.

24. Atobatele OE, Ugwumba OA. Condition factor and diet of Chrysichthys nigrodigitatus and Chrysichthys auratus (Siluriformes: Bagridae) from Aiba Reservoir, Iwo, Nigeria. Revista de Biología Tropical. 2011;59(3):1233-1244.

25. Fagbenro O, Adedire CO, Ayotunde EO, Faminu EO. Haematological profile, food composition and digestive enzyme assay in the gut of the African bony tongue, Heterotis (Clupisudis) niloticus (Cuvier 1829) (Osteoglossidae). Trop. Zool. 2000;13:1-9.

26. Offem BO, Akegbejo-Samsons Y, Omoniyi IT. Diet, size and reproductive biology of the silver catfish, Chrysichthys nigrodigitatus (Siluriformes: Bagridae) in the Cross River, Nigeria. Rev. Biol. Trop. 2008;56:1785-1799.

27. Uneke BI. Length-weight relationship and condition factor of three Chrysichthys species of the mid cross river flood system, South Eastern Nigeria. American Journal of Agricultural Science. 2015;2(2):70-74.

28. Olaosebikan BD, Raji A. Field guide to Nigerian freshwater fishes. Federal College of Freshwater Fisheries Technology, New Bussa, Nigeria; 1998.

29. Ricker WW. Computations and interpretations of biological statistics of fish populations. Bull. Fish. Res. Bd. Can. 1975;191:201-210.

30. Ugwumba AAA, Ugwumba AO. Food and feeding ecology of fishes in Nigeria. Crystal Publishers, Ajah, Lagos, Nigeria; 2007.

31. Mellanby $H$. Animal life in freshwater: A guide to freshwater invertebrates. 6th Ed. Chapman and Hall, London; 1975.

32. Bowen SH. Quantitative description of the diet. In: Nielsen LA, Johnson DL, (Eds). Fisheries Techniques. Maryland: American Fisheries Society; 1983.

33. Crisp DT, Mann RHK, McCormack JC. The effects of impoundment and regulation upon the stomach contents of fish at Sow Green, Upper Teesdale Lake. Journal of Fish Biology. 1978;12:287-301.

34. Idodo-Umeh G. Freshwater fishes of Nigeria (Taxonomy, ecological notes, diet and utilization). Idodo-Umeh Publishers Ltd. Benin City, Edo State, Nigeria; 2003.

35. Warren WG. Changes in the within-survey spatial temporal structure of the northern cod (Gadus morhua) population. Can. J. Fish. Aquat. Sci. 1993;54(1):139-148.

36. Atobatele OE. Growth pattern and morphometric discrimination of two congeneric species of Chrysichthys, $C$. nigrodigitatus and $C$. auratus (Siluriformes, Bagridae), from a small tropical reservoir. Pan-American Journal of Aquatic Sciences. 2013;8(1):62-67.

37. Ugwumba AAA, Kusemiju K. The food and feeding habits of the non-cichlid fishes of Lekki Lagoon, Nigeria. Nig. J. Sci. 1994;28(4):281-384.

38. Shep H, Konan KM, Ouattara M, Ouattara A, Gourene G. Comparative analysis of diet of two sympatric species of Tilapia in Ayame man-made lake. Livestock Res. Rur. Devt. 2013;25(9):305-312. 
39. Ekpo IE, Essien-lbok MA, Nkwoji JN. Food and feeding habits and condition factor of species in Qua Iboe River Estuary, Akwa Ibom State, South-eastern Nigeria. International Journal of Fisheries and Aquatic Studies. 2014;2(2):38-46.
40. Abowei JFN, Ezekiel EN. The Lengthweight relationship and condition factor of Chrysichthys nigrodigitatus (Lacepède, 1803) from Amassoma River flood plains. Scientia Agriculturae. 2013;3(2):3037.

(0) 2017 Esenowo et al.; This is an Open Access article distributed under the terms of the Creative Commons Attribution License (http://creativecommons.org/licenses/by/4.0), which permits unrestricted use, distribution, and reproduction in any medium, provided the original work is properly cited.

Peer-review history:

The peer review history for this paper can be accessed here: http://sciencedomain.org/review-history/20034 